PRACE GEOGRAFICZNE

zeszyt 156, 2019, 79-99

doi: 10.4467/20833113PG.19.004.10308

Instytut Geografii i Gospodarki Przestrzennej UJ

Wydawnictwo Uniwersytetu Jagiellońskiego

\title{
NATĘŻENIE RUCHU ŻEGLUGOWEGO NA DOLNEJ WIŚLE NA PODSTAWIE ANALIZY ŚLUZOWAŃ WE WŁOCŁAWKU W LATACH 1997-2016
}

\author{
Katarzyna Kubiak-Wojcicka, Tomasz Pokropski
}

\section{Intensity of inland navigation on the lower Vistula River based on the analysis of lockage in Włocławek in the years 1997-2016}

Abstract: The paper presents the usage of the lower Vistula waterway on the basis of the number of floating units passing the Włocławek lock in the period 1997-2016. The Włocławek dam plays an important role in ensuring navigability on the inland waterway on the lower Vistula. The analysis revealed that the number of units locked in the Włocławek dam varied in particular years and was decreasing throughout the whole period. It depended on the serviceability of the lock and the hydrological conditions (water levels, ice phenomena). Throughout the year, water transportation was seasonal. The highest number of passing units falls on summer months (VI-VIII). Regarding the transportation type subdivision, freight traffic dominated over touristic traffic. An exception took place in the years with low water levels (mainly in summer), in which freight traffic was impossible, which resulted in a lack of delivery guarantee. A solution to that problem is the construction of intermodal transshipment ports along the waterway.

Keywords: inland waterway, lock, Włocławek dam, freight traffic, touristic traffic, low water

Zarys treści: W artykule przedstawiono stopień wykorzystania drogi wodnej dolnej Wisły na podstawie liczby jednostek pływających śluzowanych we Włocławku w latach 1997-2016. 
Stopień wodny we Włocławku pełni ważną funkcję zapewniającą żeglowność na szlaku wodnym dolnej Wisły. Przeprowadzona analiza wykazała, że liczba jednostek śluzowanych przez stopień wodny we Włocławku jest zmienna w poszczególnych latach, a w całym wieloleciu wykazuje tendencję spadkową. Stan ten uzależniony był od sprawności technicznej śluzy oraz od warunków hydrologicznych (stanów wody i zjawisk lodowych). W ciągu roku transport wodny miał charakter sezonowy, największa liczba śluzowanych jednostek przypadała na miesiące letnie (VI-VIII). W strukturze transportu wodnego ruch towarowy dominował nad ruchem turystycznym. Wyjątek stanowiły lata z niskimi stanami wody (głównie w okresie letnim), kiedy ruch towarowy stawał się niemożliwy, co skutkowało brakiem gwarancji dostaw towarów. Rozwiązaniem tego problemu jest budowa wzdłuż dróg wodnych intermodalnych portów przeładunkowych.

Stowa kluczowe: droga wodna, śluza, stopień wodny we Włocławku, ruch towarowy, ruch turystyczny, niżówki

\section{Wstęp}

W ostatnich latach obserwuje się starania zmierzające do reaktywowania żeglugi śródlądowej w Polsce. Do pierwszych ważnych działań, które podjęto w tym zakresie należy zaliczyć utworzenie Ministerstwa Gospodarki Morskiej i Żeglugi Śródlądowej. Ministerstwo zostało powołane Rozporzqdzeniem Rady Ministrów z dnia 7 grudnia 2015 r. Kolejnym krokiem zmierzającym do poważnego traktowania działalności żeglugi śródlądowej jest podpisanie umowy AGN przez Prezydenta Rzeczypospolitej Polskiej w 2017 r. Porozumienie AGN, którego oficjalna nazwa to Europejskie Porozumienie w sprawie Gtownych Śródlądowych Dróg Wodnych o Międzynarodowym Znaczeniu (ang. European Agreement on Main Inland Waterways of International Importance) zobowiązuje Polskę m.in. do poprawy stanu dróg śródlądowych oraz zwiększenia długości dróg o znaczeniu międzynarodowym, co przełoży się na wzrost przewozów drogami śródlądowymi.

Podjęte starania i deklaracje ze strony Polski wpisują się w ogólne ramy oraz działania w zakresie polityki komunikacyjnej, wyznaczone przez Komisję Europejską. Transport wodny śródlądowy uważa się za najbardziej bezpieczny, energooszczędny, tani i przyjazny środowisku spośród znanych rodzajów transportu (Wojewódzka-Król 1987; Kulczyk, Winter 2003; Rohács, Simongáti 2007; Bolt, Jerzyło 2013a). Jednak w ciągu ostatnich lat zaobserwowano zmniejszenie lub w najlepszym wypadku stagnację udziału transportu wodnego śródlądowego w przewozach ogółem w Europie (Caris i in. 2014; Wiegmans, Konings 2017). Stąd też Komisja Europejska kładzie duży nacisk na podjęcie długoterminowych inwestycji w zakresie infrastruktury transportowej, co przyczyni się do postępu w dziedzinie zrównoważonego transportu (Ivaković i in. 2008; Lopez-Navarro 2013). Idea zrównoważonego transportu polega na efektywnej komunikacji, korzystnej ekonomicznie i minimalizującej 
szkodliwy wpływ pojazdów na środowisko. Szczegółową definicję przedstawia Organizacja Współpracy Gospodarczej i Rozwoju (1996), według której zrównoważony transport to „transport, który nie zagraża ludzkiemu zdrowiu i ekosystemom oraz pozwala zaspokoić potrzeby transportowe poprzez zrównoważone wykorzystanie odnawialnych zasobów w ilości mniejszej niż wynosi ich stopa regeneracji oraz używanie nieodnawialnych zasobów w ilości niższej niż wynosi stopa rozwoju odnawialnych substytutów”. Jednym z celów strategicznych Biatej Ksiegi Transportu (2011) jest przeniesienie do 2030 r. drogowego transportu towarów na odległość większą niż $300 \mathrm{~km}$ na inne środki transportu, np. kolej lub transport wodny, które charakteryzują się relatywnie małym zużyciem energii i niską emisyjnością zanieczyszczeń powietrza. Osiągnięcie tego celu będzie w Polsce dużym wyzwaniem z uwagi na znikomy udział śródlądowego transportu wodnego w transporcie ogółem.

Pod względem geograficznym Polska stanowi ważne ogniwo w europejskiej sieci dróg wodnych. Przez teren Polski przebiegają 3 międzynarodowe drogi wodne: E-30, E-40 i E-70 (ryc. 1).

Pomimo korzystnego układu sieci hydrograficznej śródlądowe drogi wodne w Polsce są w niewielkim stopniu wykorzystane do celów transportowych, co wynika głównie z ich niezadowalającego stanu oraz infrastruktury technicznej (Babiński 2013; Bolt, Jerzyło 2013b; Najwyższa Izba Kontroli 2013; Wojewódzka-Król, Rolbiecki 2013; Smolnik 2016). Wśród innych barier rozwoju żeglugi śródlądowej w Polsce należy wymienić brak węzłów transportowych, które włączają się w łańcuchy dostaw (Montwiłł 2013), a także barierę społeczną i politykę transportową kraju (Jarzębińska 2008). W powszechnej opinii żegluga śródlądowa jest przestarzałym, powolnym i nieefektywnym środkiem transportu, a niejednokrotnie wskazuje się, że przyczynia się ona do dewastacji środowiska przyrodniczego, w tym wodnego. Opinie te powiela się bez wskazania konkretnych argumentów. Należy zgodzić się z Miką (2000), że niektóre z ujemnych skutków procesu inwestycyjnego są nie do uniknięcia lub są niezbędne dla zapewnienia jego prawidłowego przebiegu. Zmiany w środowisku związane z inwestycjami, zwłaszcza w turystyce wodnej, cechuje trwały charakter. Polityka transportowa kraju stanowi barierę w rozwoju, ponieważ nie przewiduje rozwoju śródlądowych dróg wodnych w najbliższych latach, co potwierdza zapis w dokumencie, jakim jest Strategia rozwoju transportu do 2020 roku z perspektywa do 2030 roku (2013). Ministerstwo Gospodarki Morskiej i Żeglugi Śródlądowej dopiero przystąpiło do prac nad programem wieloletnim, zmierzającym do przywrócenia parametrów eksploatacyjnych na śródlądowych drogach wodnych pełniących funkcję transportową.

W niniejszym opracowaniu skupiono się na odcinku dolnej Wisły od ujścia Narwi do ujścia do Morza Bałtyckiego, który jest niezwykle ważny, bowiem przebiegają tędy dwie międzynarodowe drogi wodne: E-40 i E-70. Podjęty w artykule problem dotyczy 
stopnia wykorzystania infrastruktury technicznej w transporcie wodnym śródlądowym z uwzględnieniem zmian reżimu hydrologicznego rzeki. Warto zwrócić uwagę, że Wisła poza funkcją transportową pełni wiele innych funkcji (np. energetyczną, ekologiczną), które odgrywają istotną rolę w środowisku przyrodniczym (Kubiak-Wójcicka i in. 2017; Duda-Gromada 2018). Należy to uwzględnić przy planowaniu prac rewitalizacyjnych dróg wodnych w najbliższej przyszłości.

\section{Cel i metody pracy}

Celem niniejszego opracowania jest charakterystyka natężenia ruchu żeglugowego na śluzie we Włocławku, co pozwoli ocenić rolę transportową dolnej Wisły. Zagadnienie ruchu żeglugowego zostało przedstawione na podstawie danych dotyczących liczby i rodzaju jednostek pływających, które pokonywały stopień wodny we Włocławku. Dane zostały uzyskane dzięki uprzejmości Regionalnego Zarządu Gospodarki Wodnej (RZGW) w Warszawie. Ewidencja wykorzystania śluzy prowadzona przez pracowników RZGW obejmuje podział jednostek pływających ze względu na ich rodzaj, tj. barki, pchacze i holowniki, statki pasażerskie oraz pozostałe statki. Ruch towarowy obejmuje liczbę śluzowanych barek, pchaczy i holowników. Z kolei do ruchu turystycznego zaliczono statki pasażerskie oraz pozostałe, np. motorówki, kajaki, jachty, a także jednostki związane z administracją szlaku wodnego (jednostki RZGW), a także jednostki Wodnego Ochotniczego Pogotowia Ratunkowego (WOPR) i policji.

W opracowaniu przeanalizowano strukturę natężenia ruchu, z podziałem na ruch towarowy i turystyczny w latach 1997-2016 w ujęciu rocznym i sezonowym. Wielkość natężenia ruchu żeglugowego we Włocławku zestawiono z warunkami hydrologicznymi, jakie panowały na Wiśle w tym okresie. Posterunek wodowskazowy we Włocławku położony jest poniżej stopnia wodnego, na 679,4 km rzeki Wisły. Jednak z uwagi na nasiloną erozję dna koryta rzecznego (Babiński, Habel 2013) i związaną z tym zmianą zera wodowskazu w 2004 r., wykorzystane zostały dane z posterunku wodowskazowego w Toruniu. Codzienne stany wody Wisły z tego posterunku uzyskano z Instytutu Meteorologii i Gospodarki Wodnej - Państwowego Instytutu Badawczego (IMGW-PIB). Wyznaczanie niskich stanów wody Wisły w latach 1997-2016 przeprowadzono w oparciu o metodę Threshold Level Methods (TLS), tj. odcięcie hydrogramów poniżej średnich niskich stanów wody wyznaczonych dla wielolecia 1951-2010 w Toruniu (179 cm) (Kubiak-Wójcicka 2012). Analogicznie wyznaczono okresy z wezbraniami, podczas których poziom wody na Wiśle w Toruniu został przekroczony ponad stan alarmowy $(650 \mathrm{~cm})$ (Kubiak-Wójcicka 2014a). Uzyskane wyniki pozwoliły określić, przez jaki czas w ciągu roku żegluga na Wiśle była niemożliwa lub utrudniona z uwagi na niekorzystne warunki hydrologiczne. 


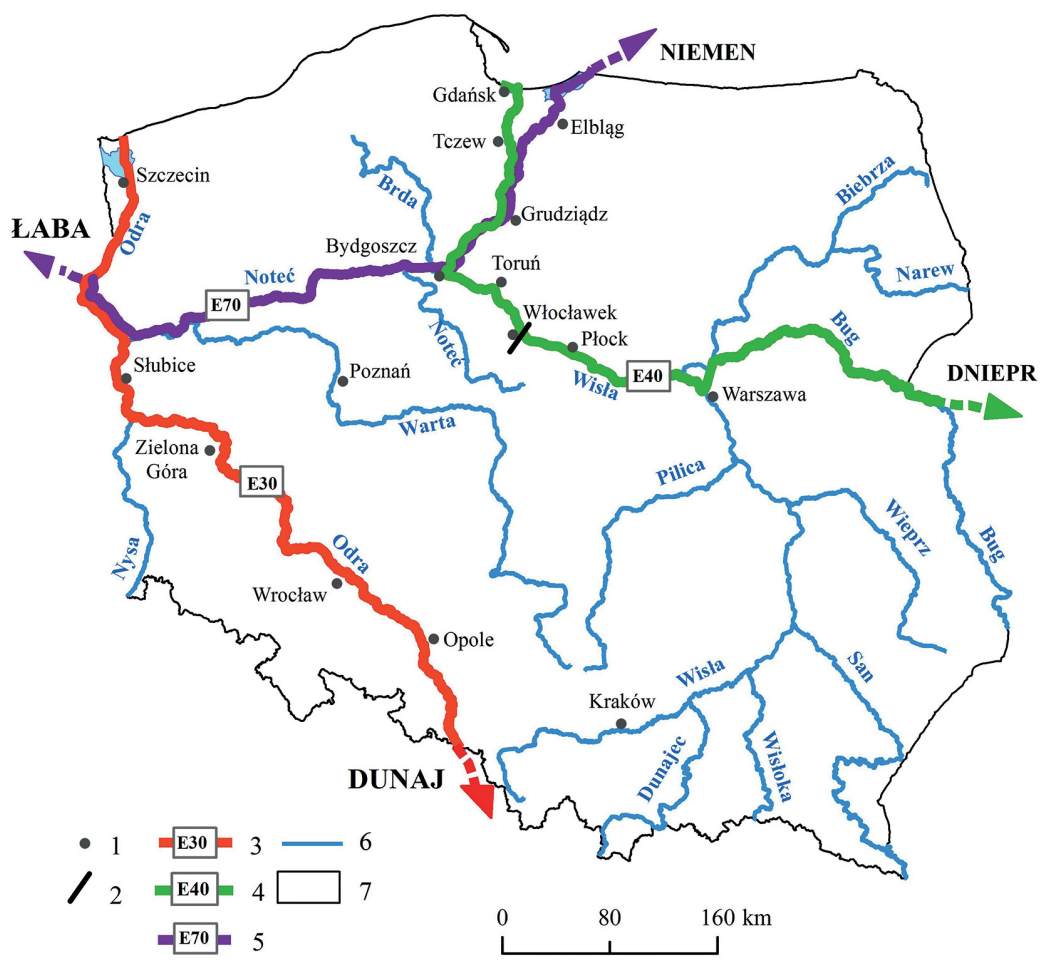

Ryc. 1. Międzynarodowe drogi wodne na terenie Polski

Fig. 1. International waterways in Poland

Objaśnienia: 1 - miasto, 2 - zapora, 3 - droga E-30, 4-droga E-40, 5 - droga E-70, 6-rzeka, 7 - granica państwa.

Explanations: 1 - city, 2 - dam, 3 - waterway E-30, 4 - waterway E-40, 5 - waterway E-70, 6 - rivers, 7 - state border. 


\section{Śródlądowe drogi wodne w Polsce}

Układ śródlądowych dróg wodnych uzależniony jest w głównej mierze od naturalnego układu sieci hydrograficznej, która przebiega południkowo. Konieczność połączeń dróg wodnych w kierunku wschód-zachód zapoczątkowała w XVIII w. budowę sztucznych kanałów (Kubiak-Wójcicka 2014b). Do głównych dróg wodnych zaliczono rzeki Odrę i Wisłę oraz drogę wodną Wisła-Odra. Klasyfikacje dróg wodnych w Polsce przedstawiono w tab. 1.

W Polsce całkowita długość dróg wodnych w 2016 r. wynosiła 3655 km (w tym $2417 \mathrm{~km}$ uregulowanych rzek żeglownych, 644 km skanalizowanych odcinków rzek, $336 \mathrm{~km}$ kanałów i $259 \mathrm{~km}$ jezior żeglownych). Faktycznie eksploatowanych przez żeglugę było 3365 km (92,1\%) dróg żeglownych. Dostosowanie wymiaru statków i dróg wodnych jest głównym czynnikiem determinującym efektywność transportu wodnego śródlądowego. Wymagania stawiane drogom o znaczeniu międzynarodowym (klasy IV i V) w 2016 r. spełniało w Polsce 5,9\% długości dróg wodnych $(214 \mathrm{~km})$. Jest to wartość, która pozostaje na niezmienionym poziomie od 2007 r., podobnie jak w przypadku całkowitej długości dróg wodnych. Pozostałą sieć dróg wodnych tworzą drogi o znaczeniu regionalnym klasy I, II i III, których łączna długość w 2016 r. wyniosła 3441 km (94,1\%) (Transport wodny... , 2017).

Droga wodna na odcinku dolnej Wisły (od ujścia Narwi do ujścia do Morza Bałtyckiego) ma zróżnicowany charakter. Najdłuższy odcinek stanowi droga wodna II klasy, która ma długość 190,5 km i obejmuje trasę od ujścia rzeki Tążyny do miejscowości Tczew. Najgorsze parametry na odcinku dolnej Wisły ma droga wodna klasy Ib. Na odcinku tym droga wodna klasy Ib łącznie obejmuje $117 \mathrm{~km}$, w tym jest to odcinek od Zakroczymia do Płocka $(74 \mathrm{~km})$ oraz od Włocławka do ujścia Tążyny (43 km). W odcinku ujściowym Wisły żegluga może się odbywać w dwóch wariantach. Pierwszy obejmuje odcinek Wisły od Tczewa do granicy z morzem (III klasa drogi wodnej). Wariant drugi obejmuje drogę wodną Martwą Wisłą od miejscowości Przegalina nad Wisłą aż do granicy z morzem (klasa Vb). Droga wodna Martwą Wisłą ma rangę międzynarodową, jednak wymaga śluzowania na śluzie w Przegalinie. Najlepsze parametry ma droga wodna Wisły powyżej stopnia we Włocławku (klasa $\mathrm{Vb}$ ), natomiast poniżej stopnia jest to zaledwie klasa Ib.

Aby droga wodna spełniała parametry drogi międzynarodowej (IV klasy), minimalna szerokość szlaku żeglownego musi wynosić $40 \mathrm{~m}$, a minimalna głębokość tranzytowa 2,8 m. Minimalne wymiary śluzy dla drogi IV klasy to $12 \mathrm{~m}$ szerokości i $120 \mathrm{~m}$ długości (tab. 2).

Przebycie całego odcinka drogi wodnej E-40 wymaga pokonania jedynego na Wiśle stopnia wodnego we Włocławku, który został oddany do użytku w 1970 r. Śluza żeglugowa z awanportami zlokalizowana jest na lewym brzegu Wisły. Szerokość śluzy wynosi 12 m, natomiast jej długość 115 m. Projektowana minimalna głębokość 


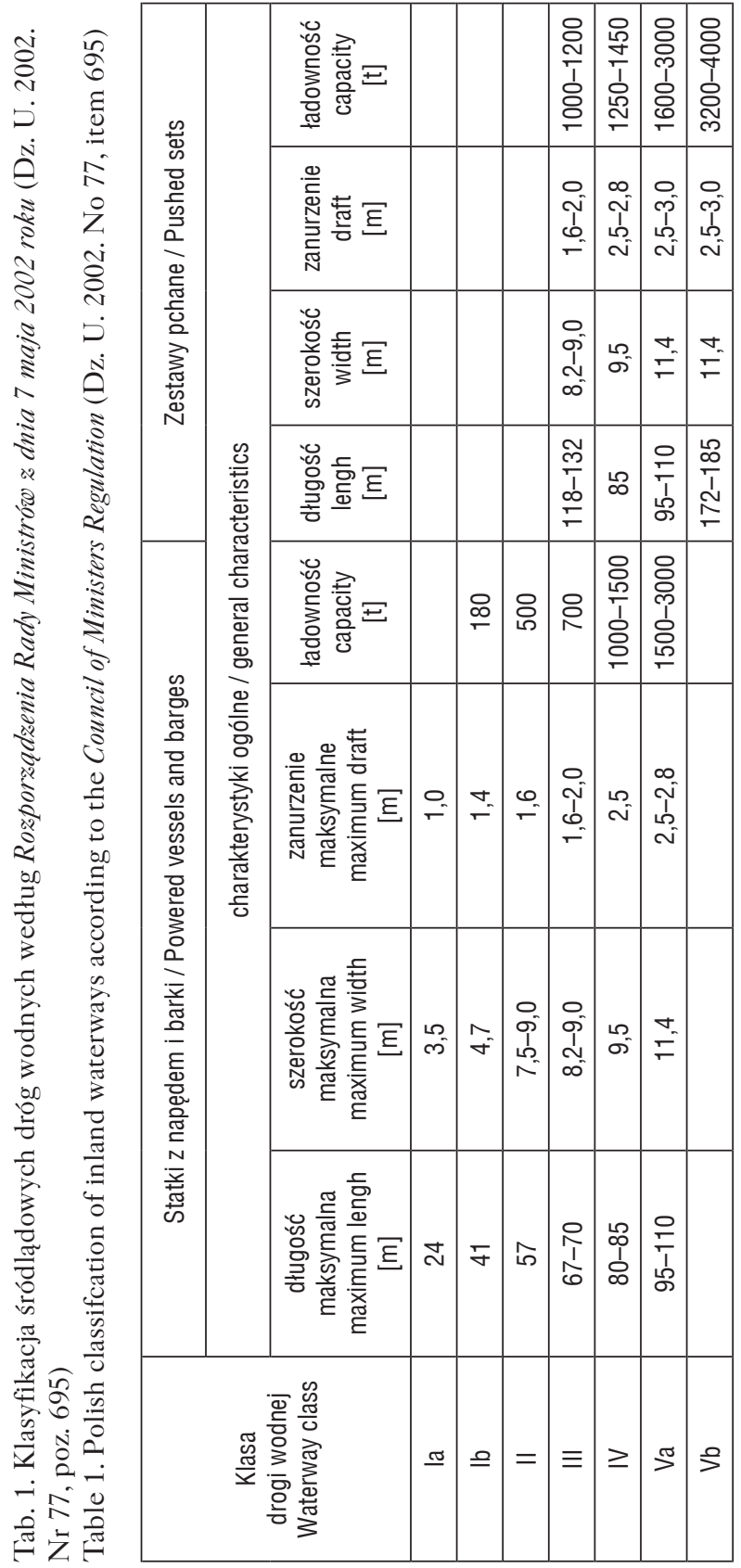


Tab. 2. Parametry eksploatacyjne śródlądowych dróg wodnych według Rozporzqdzenia Rady Ministrów z dnia 7 maja 2002 roku (Dz. U. 2002. Nr 77, poz. 695)

Table 2. Inland waterway operating parameters according to the Council of Ministers Regulation (Dz. U. 2002. No. 77, item 695)

\begin{tabular}{|c|c|c|c|c|c|c|c|c|}
\hline \multirow{3}{*}{$\begin{array}{l}\text { Parametry eksploatacyjne } \\
\text { Operating parameters }\end{array}$} & \multicolumn{8}{|c|}{ Wartości parametrów / Parameters' values } \\
\hline & \multirow{2}{*}{$\begin{array}{c}\text { jednostki } \\
\text { miary } \\
\text { measurement } \\
\text { units }\end{array}$} & \multicolumn{7}{|c|}{ klasy / classes } \\
\hline & & la & $\mathrm{lb}$ & $\|$ & III & IV & Va & $\mathrm{Vb}$ \\
\hline \multicolumn{9}{|c|}{ Minimalne wymiary szlaku żeglownego w rzece / Minimum dimensions of a river waterway } \\
\hline $\begin{array}{l}\text { Szerokość szlaku żeglownego } \\
\text { Waterway width }\end{array}$ & \multirow{3}{*}{$\mathrm{m}$} & 15 & 20 & 30 & 40 & 40 & 50 & 50 \\
\hline $\begin{array}{l}\text { Głębokość tranzytowa / Waterway } \\
\text { depht }\end{array}$ & & 1,2 & 1,6 & 1,8 & 1,8 & 2,8 & 2,8 & 2,8 \\
\hline $\begin{array}{l}\text { Promień łuku osi szlaku } \\
\text { żeglownego / Curve radius of the } \\
\text { waterway axis }\end{array}$ & & 100 & 200 & 300 & 500 & 650 & 650 & 800 \\
\hline \multicolumn{9}{|c|}{ Minimalne wymiary kanału / Minimum dimensions of a canal } \\
\hline $\begin{array}{l}\text { Szerokość szlaku żeglownego } \\
\text { Waterway width }\end{array}$ & \multirow{3}{*}{$\mathrm{m}$} & 12 & 18 & 25 & 35 & 40 & 45 & 45 \\
\hline $\begin{array}{l}\text { Najmniejsza głębokość wody } \\
\text { w kanale / Minimum water depth } \\
\text { in a canal }\end{array}$ & & 1,5 & 2,0 & 2,2 & 2,5 & 3,5 & 3,5 & 3,5 \\
\hline $\begin{array}{l}\text { Promień łuku osi szlaku } \\
\text { żeglownego / Curve radius of the } \\
\text { waterway axis }\end{array}$ & & 150 & 250 & 400 & 600 & 650 & 650 & 800 \\
\hline \multicolumn{9}{|c|}{ Minimalne wymiary śluz żeglugowych / Minimum dimensions of navigation locks } \\
\hline Szerokość śluzy / Lock width & \multirow{3}{*}{$\mathrm{m}$} & 3,3 & 5,0 & 9,6 & 9,6 & 12,0 & 12,0 & 12,0 \\
\hline Długość śluzy / Lock length & & 25 & 42 & 65 & 72 & 120 & 120 & 187 \\
\hline $\begin{array}{l}\text { Głębokość na progu dolnym / Depth } \\
\text { on the lower step of a lock }\end{array}$ & & 1,5 & 2,0 & 2,2 & 2,2 & 3,5 & 4,0 & 4,0 \\
\hline
\end{tabular}

na progu dolnym wynosiła 3,5 m, przy maksymalnym spadzie $12,8 \mathrm{~m}$. Obecnie minimalna głębokość jest uzależniona od przepływu przez stopień. Przy przepływie zbliżonym do gwarantowanego $\left(350 \mathrm{~m}^{3} / \mathrm{s}\right)$ i niższym głębokość spada poniżej $1 \mathrm{~m}$. Przy przepływie do $600 \mathrm{~m}^{3} / \mathrm{s}$ głębokość jest mniejsza niż $1,6 \mathrm{~m}$, tj. poniżej wymagań klasy Ib. Spad przy przepływach zbliżonych do gwarantowanego wynosi ponad $14 \mathrm{~m}$. Śluza zamykana jest od strony wody górnej stalowymi, segmentowymi wrotami, natomiast od strony wody dolnej stalowymi wrotami wspornymi. 


\section{Transport wodny śródlądowy}

Stan drogi wodnej i jej faktycznych parametrów w głównej mierze decyduje o wielkości przewozów transportowanych wodnymi drogami śródlądowymi. Ogółem ilość przetransportowanych ładunków w Polsce w 2016 r. wyniosła 1836652 ton, w tym na transport samochodowy przypadało $84,2 \%$, na kolejowy $12,1 \%$, a na żeglugę śródlądową $0,3 \%$ ogółem przewiezionych ładunków. Biorąc pod uwagę ładunki transportowane drogą wodną śródlądową w przeliczeniu na tonokilometry, udział transportu wodnego stanowił 0,2\% ogółu transportu w 2016 r., natomiast w 2014 r. udział ten wynosił zaledwie 0,1\% (Transport wodny...., 2017). W porównaniu z krajami Unii Europejskiej udział transportu wodnego śródlądowego odgrywa marginalną rolę w polskim i europejskim systemie transportowym. Największy udział śródlądowego transportu wodnego w krajach Unii Europejskiej w transporcie ogółem w tonokilometrach w 2014 r. miały: Holandia (44,2\%), Rumunia (28,3\%), Bułgaria (26,1\%), Belgia (15,6\%), Niemcy $(9,6 \%)$ i Luksemburg $(8,4 \%)$ (Transport wodny..., 2017). Dominacja tych krajów w przewozach żeglugą śródlądową wynika z ich usytuowania w centrum europejskiej sieci wodnej oraz połączenia z portami morskimi.

Niewielka liczba przewożonych ładunków przekłada się na małe wpływy finansowe przedsiębiorstw, co w znacznej mierze ogranicza możliwości inwestycyjne. Obecnie większa część taboru żeglugi śródlądowej jest zdekapitalizowana, przekracza normatywny okres użytkowania, a dalsza eksploatacja możliwa jest jedynie dzięki stałej modernizacji. Według danych z 2016 r. większość wykorzystywanych pchaczy $(74,6 \%)$, niemal połowa barek do pchania $(48,6 \%)$ oraz wszystkie barki z własnym napędem zostały wyprodukowane w latach 1949-1979 (Transportwodny..., 2017). Na odcinku dolnej Wisły funkcjonuje kilku przewoźników śródlądowych, którzy świadczą usługi przewozu towarów i pasażerów drogami śródlądowymi. Są to firmy, które powstały w wyniku przekształceń organizacyjno-własnościowych polskich przedsiębiorstw żeglugi śródlądowej w latach 90. XX w. Do największych firm działających na dolnej Wiśle należy zaliczyć Żeglugę Bydgoską, którą w 1995 r. przekształcono w jednoosobową spółkę Skarbu Państwa (Taylor, Ciechański 2011), a która obecnie wchodzi w skład OT Logistic Group.

Żegluga śródlądowa obejmuje nie tylko ruch towarowy, ale również turystyczny. Jednostki turystyczne, które w większości pływają po dolnej Wiśle nie wymagają dużych głębokości, jak to jest w przypadku ruchu towarowego, co wynika z ich wyporności. Głębokość $1 \mathrm{~m}$ będzie wystarczająca dla małych jednostek pływających (jachty, motorówki), jednak dla jednostek towarowych nie wystarczy. Z punktu widzenia turystycznego w ciągu ostatnich lat zaszły zmiany w turystyce wodnej (Kruczek, Banasik 2014). Wynikają one głównie z liberalizacji przepisów związanych z uprawianiem turystyki wodnej, które zostały wprowadzone zgodnie z Rosporsqdzeniem Ministra Sportu i Turystyki z dnia 9 kwietnia 2013 roku (Dz. U. 2013, poz. 460). Nowe rozporządzenie 
znosi rygorystyczne przepisy w zakresie uprawiania turystyki wodnej, m.in. zawiera uproszczony system patentowy oraz zwalnia z obowiązku posiadania dokumentu kwalifikacyjnego chętnych do uprawiania turystyki wodnej dla jachtów żaglowych o długości kadłuba poniżej 7,5 m lub łodzi motorowych o mocy silnika poniżej $10 \mathrm{~kW}$. Drugim elementem wpływającym na większe zainteresowanie turystyką wodną jest rozwój infrastruktury turystycznej, m.in. budowa przystani rzecznych, marin, wypożyczalni sprzętu wodnego. Dodatkowo większemu zainteresowaniu turystyką wodną sprzyja tworzenie i udostępnianie bezpłatnych aplikacji mobilnych na telefony komórkowe oraz stron internetowych umożliwiających wyczarterowanie jednostek pływających. Jako przykład może służyć Wielka Pętla Wielkopolska lub Pętla Żuławska.

\section{Wyniki analizy liczby śluzowań na stopniu wodnym we Włocławku w latach 1997-2016}

W celu określenia natężenia ruchu żeglugowego i wykorzystania infrastruktury technicznej w żegludze śródlądowej na dolnej Wiśle przeanalizowano liczbę śluzowań we Włocławku w latach 1997-2016 z uwzględnieniem liczby śluzowań ogółem oraz w podziale na ruch towarowy i turystyczny (ryc. 2).

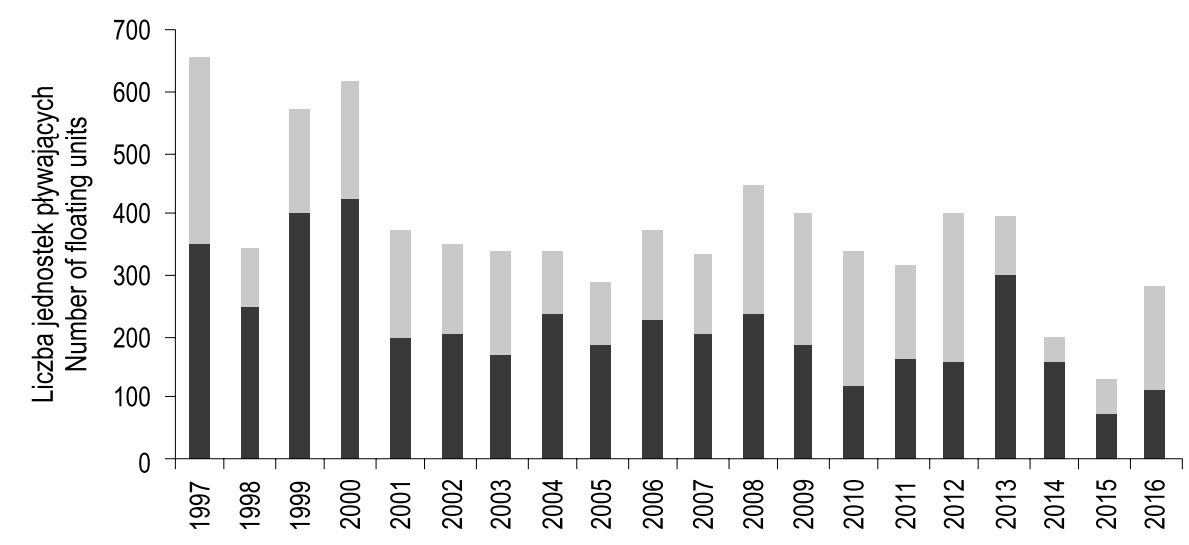

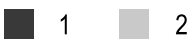

Ryc. 2. Liczba jednostek pływających w ruchu towarowym i turystycznym śluzowanych we Włocławku w latach 1997-2016

Fig. 2. Number of floating units passing the Włocławek lock in the period 1997-2016 divided by traffic type (freight versus touristic)

Objaśnienia: 1 - ruch towarowy, 2 - ruch turystyczny.

Explanations: 1 - freight traffic, 2 - touristic traffic. 


\section{Ruch ogółem}

Liczba wszystkich śluzowanych obiektów w analizowanym wieloleciu 1997-2016 była zróżnicowana i wahała się od 656 jednostek pływających w 1997 r. do zaledwie 129 w 2015 r. Średnia liczba jednostek śluzowanych w badanych latach wynosiła 375. Przyczyną wyjątkowo małej liczby śluzowań na stopniu w 2015 r. (prawie o połowę mniej niż w 2014 r.) były warunki hydrologiczne, jakie panowały w korycie Wisły. Zanotowano wtedy rekordowo niskie stany wody w Wiśle, co uniemożliwiało żeglugę jednostek o zanurzeniu większym niż $30 \mathrm{~cm}$. Według danych IMGW-PIB na posterunku we Włocławku zanotowano stan wody równy $87 \mathrm{~cm}$, który utrzymywał się od 30 sierpnia do 8 września 2015 r., natomiast na posterunku w Toruniu najniższy stan wody wynosił $94 \mathrm{~cm}$ i wystąpił 3, 5, 6 i 8 września 2015 r. Stan ten należał do najniższych w całym okresie systematycznych obserwacji hydrologicznych. Dodatkowym elementem decydującym o niewielkiej liczbie śluzowań był remont śluzy, który rozpoczął się pod koniec 2013 r. i trwał do 2015 r. Śluzowania były realizowane w ograniczonym zakresie, wyłącznie po wcześniejszym uzgodnieniu z RZGW oraz wykonawcą prac remontowych. Stąd też niewielka liczba jednostek śluzowanych w 2014 r. Brak śluzowań lub ich pojedyncze przypadki miały miejsce w sierpniu, wrześniu i październiku, kiedy przeprowadzano prace związane z zabezpieczeniem antykorozyjnym wrót śluzy.

\section{Ruch towarowy i turystyczny}

Szczegółowa analiza danych wykazała, że intensywność ruchu żeglugowego z podziałem na towarowy i turystyczny jest zmienna. Do ruchu towarowego zaliczono barki, pchacze i holowniki. Ruch turystyczny to głównie statki pasażerskie oraz pozostałe jednostki, do których zaliczono m.in.: łodzie sportowe i turystyczne, kajaki, jachty, motorówki, skutery. Ruch towarowy przeważa nad ruchem turystycznym w analizowanym wieloleciu. Wyjątki miały miejsce w latach: 2002, 2009, 2010, 2012 i 2016, kiedy przeważał ruch jednostek turystycznych. W wymienionych latach (poza 2010 r.) występowały niskie stany wody w rzece w ciągu całego roku, co przekłada się na głębokość tranzytową szlaku wodnego. Pchacze i holowniki muszą mieć zapewnione przynajmniej 1,6 m głębokości w najpłytszym miejscu. Ruch małych jednostek pływających, np. kajaków, skuterów lub motorówek, może odbywać się, gdy głębokości będą mniejsze, np. ok. $1 \mathrm{~m}$. W 2010 r. stany wody w Wiśle utrzymywały się powyżej stanów średnich, a mimo to zanotowano przewagę ruchu turystycznego nad towarowym. Wynikało to głównie ze śluzowania jednostek należących do służb, które monitorowały poziom wody w Wiśle podczas przejścia fali powodziowej w maju i czerwcu 2010 r., np. WOPR, policja lub administracja szlaku. Jednostki 
związane $\mathrm{z}$ administracją drogi wodnej z reguły odbywały trzy śluzowania w ciągu roku, co związane było z utrzymaniem szlaku wodnego. Pozostałe jednostki, np. WOPR i policja wodna, do 2010 r. łącznie odbywały ok. 10 śluzowań w ciągu roku. Po 2010 r. liczba jednostek śluzowanych przez policję i WOPR zmalała praktycznie do zera z uwagi na zakup dodatkowych jednostek dla ww. służb, które stacjonowały na odcinku Wisły poniżej, jak i powyżej stopnia wodnego. Poza tym w 2014 r. oddano do użytku przystań położoną poniżej stopnia wodnego we Włocławku, w pobliżu ujścia rzeki Zgłowiączki, co również wpłynęło na zmniejszenie liczby koniecznych śluzowań.

Poza zmiennością roczną liczby śluzowanych obiektów dokonano analizy w rozkładzie miesięcznym. Żegluga na Wiśle ma charakter sezonowy, odbywa się głównie w półroczu letnim, tj. od maja do października. Przeciętnie w badanym wieloleciu stanowi ok. $73 \%$ wszystkich śluzowanych jednostek w danym roku. Udział procentowy jednostek śluzowanych tylko w trzech miesiącach, tj. w czerwcu, lipcu i sierpniu w stosunku do półrocza letniego $(\mathrm{V}-\mathrm{X})$ wynosił średnio 66\%. Udział procentowy jednostek śluzowanych w trzech miesiącach letnich waha się od 29 do $66 \%$ w stosunku do liczby śluzowań w całym roku. Wskazane miesiące letnie (VI-VIII) są optymalne w klimacie Polski do uprawiania turystyki wodnej z uwagi na sprzyjające warunki meteorologiczne (miesiące najcieplejsze w roku) oraz okres wypoczynkowy (sezon wakacyjny i urlopowy). W okresie tym organizowane są różne imprezy okolicznościowe lub regaty, które przyciągają właścicieli lub użytkowników jednostek turystycznych. Z drugiej strony, wymienione miesiące są pod względem hydrologicznym najbardziej zmienne z uwagi na częstotliwość występowania wysokich i niskich stanów wody. Ma to swoje odzwierciedlenie w liczbie śluzowanych jednostek. W jednym roku notuje się najwyższą liczbę jednostek pokonujących drogę wodną, a w kolejnym roku najniższą. Struktura natężenia ruchu żeglugowego również jest niejednolita. Największy ruch turystyczny zanotowano w miesiącach letnich (ryc. 3), natomiast ruch towarowy w miesiącach wiosennych i jesiennych (ryc. 4). Żegluga w okresie zimowym (XI-IV) praktycznie ustaje z uwagi na potencjalne zjawiska lodowe, chociaż w ostatnich latach pojawiają się one znacznie rzadziej.

Największa liczba jednostek towarowych była śluzowana w lipcu 2013 r. (107 jednostek), natomiast jednostek turystycznych w czerwcu 2009 r. (102 jednostki). Brak śluzowań jednostek pływających towarowych lub turystycznych wynika głównie z remontu śluzy. Remonty takie były prowadzone w czerwcu i lipcu 2005 r. oraz w latach 2013-2015. Brak śluzowania jednostek towarowych w lipcu 2003 r. wynika z bardzo niskich stanów wody w rzece i zbyt małej głębokości gwarantowanej.

Towar przewożony barkami to głównie piasek i żwir pochodzący z wydobycia z dna Wisły. W sytuacji gdy występują niskie stany wody i niemożliwa jest żegluga towarowa, część ruchu przełożona jest na pozostałe miesiące w roku pod warunkiem, że nie występują zjawiska lodowe i możliwe jest wydobycie piasku z rzeki. 


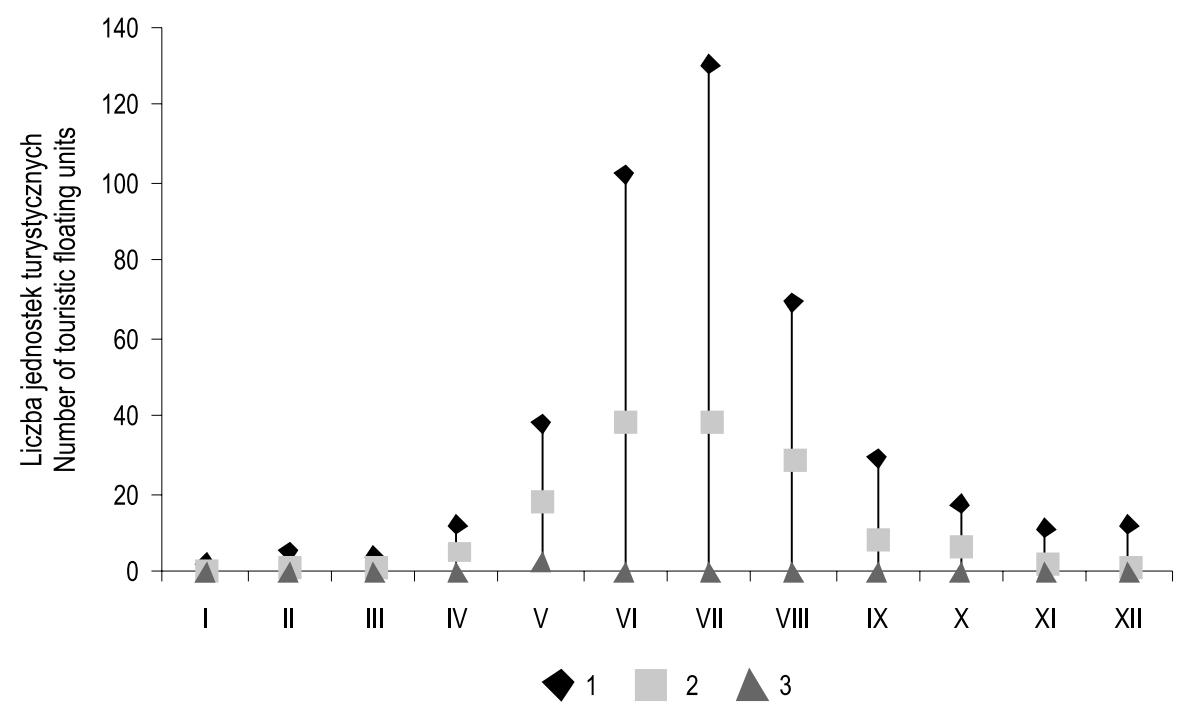

Ryc. 3. Maksymalna, średnia i minimalna liczba jednostek turystycznych śluzowanych we Włocławku w poszczególnych miesiącach w latach 1997-2016

Fig. 3. Maximum, average and minimum number of touristic floating units passing the Włocławek lock in particular months in the period of 1997-2016

Objaśnienia: 1 - maksymalne, 2 -średnie, 3 -minimalne.

Explanations: 1 - maximum, 2 -average, 3 - minimum.

Gdy niekorzystna sytuacja hydrologiczna utrzymuje się przez większość roku, ruch żeglugowy jest zdecydowanie mniejszy i nie ma możliwości zwiększenia ruchu towarowego. Poza piaskiem i żwirem transportuje się również ładunki ponadgabarytowe (np. turbiny gazowe, silosy itp.), jednak stanowią one marginalny udział $\mathrm{w}$ transporcie towarowym.

\section{Wpływ stanów wody na Wiśle na natężenie ruchu żeglugowego}

\section{Niskie stany wody w Wiśle}

Natężenie ruchu żeglugowego jest uzależnione w głównej mierze od stanów wody w korycie. W przypadku niskich stanów wody występują ograniczenia w ruchu przewozowym, co widoczne jest w mniejszej liczbie śluzowanych obiektów. Przy 


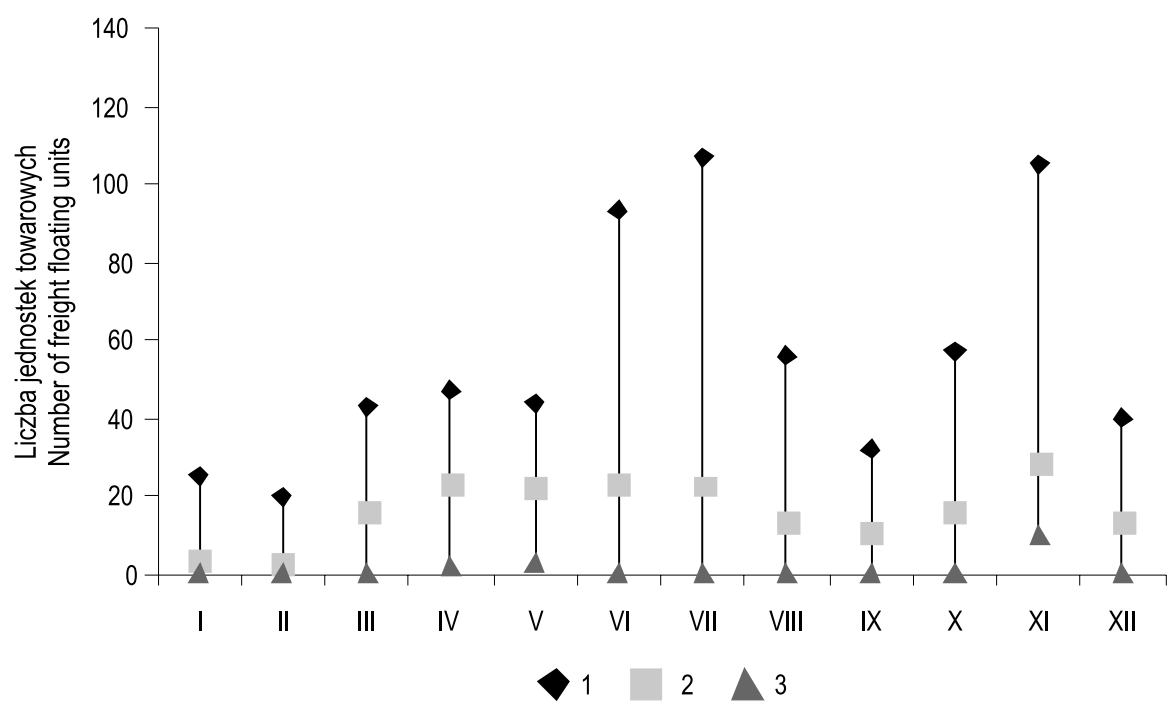

Ryc. 4. Maksymalna, średnia i minimalna liczba jednostek towarowych śluzowanych we Włocławku w poszczególnych miesiącach w latach 1997-2016

Fig. 4. Maximum, average and minimum number of freight floating units passing the Włocławek lock in particular months in the period of 1997-2016

Objaśnienia: 1 - maksymalna, 2 - średnia, 3 - minimalna.

Explanations: 1 - maximum, 2 - average, 3 - minimum.

założeniu, że za utrudnienia w żegludze odpowiada stan wody Wisły w Toruniu, wynoszący SNW (średnia niska woda), tj. $179 \mathrm{~cm}$ i stan alarmowy zbliżony do SWW (średnia wysoka woda), tj. $650 \mathrm{~cm}$, oszacowano średni czas niedostępności rzeki dla celów żeglugowych poniżej stopnia wodnego.

W ciągu analizowanego wielolecia 1997-2016 średnio przez 10,8\% roku ruch żeglugowy był niemożliwy z uwagi na zbyt niskie lub zbyt wysokie stany wody. Przewagę miały niskie stany wody, które w 2015 r. stanowiły aż 41,1\% dni w ciągu roku, natomiast najwyższe stany wody obejmowały 6,3\% dni w 2010 r. Przy założeniu, że przyjęte będzie bardziej rygorystyczne kryterium wyznaczania niżówek, jakie zastosowali Gorączko i in. (2013), tj. stan wody Wisły poniżej $240 \mathrm{~cm}$, to czas, kiedy Wisła nie będzie mogła być wykorzystana dla potrzeb żeglugi towarowej, może stanowić nawet do $61 \%$ całego roku, tak jak to miało miejsce w 2015 r.

Biorąc pod uwagę liczbę dni w poszczególnych miesiącach, kiedy żegluga nie mogła się odbywać (stany wody poniżej $240 \mathrm{~cm}$ i powyżej $650 \mathrm{~cm}$ ), w całym 


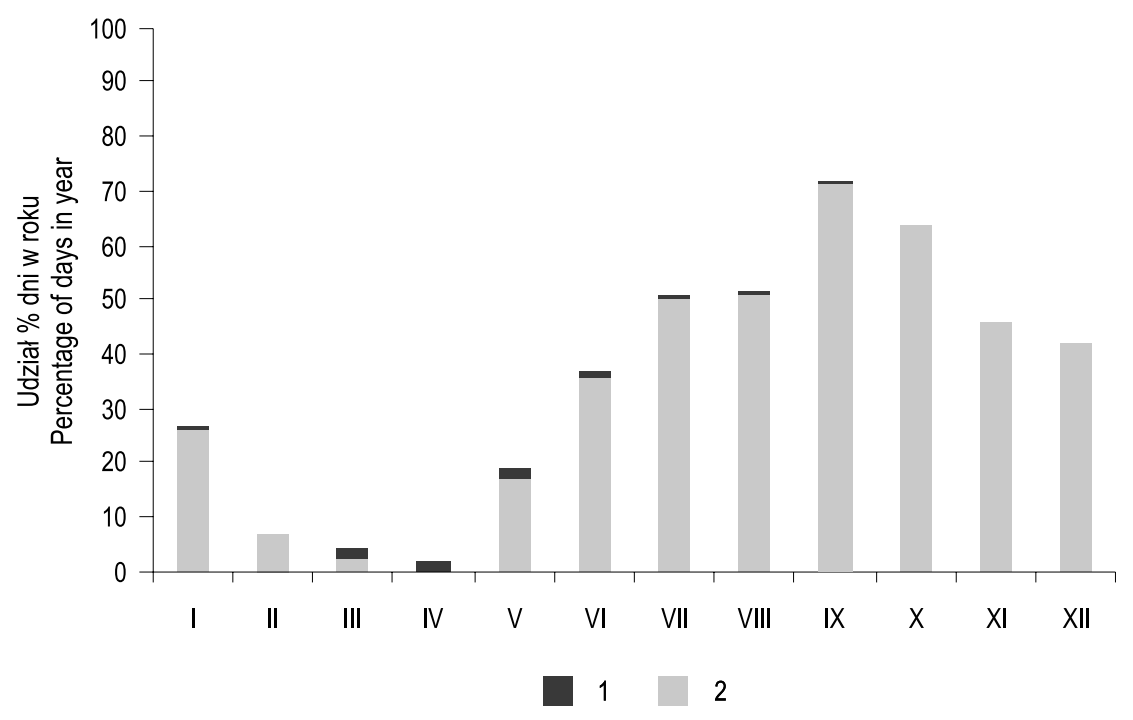

Ryc. 5. Udział procentowy dni z niskimi $(\leq 240 \mathrm{~cm})$ i wysokimi $(\geq 650 \mathrm{~cm})$ miesięcznymi stanami wody Wisły w Toruniu w latach 1997-2016

Fig. 5. Percentage of days with low $(\leq 240 \mathrm{~cm})$ and high $(\geq 650 \mathrm{~cm})$ water levels of the Vistula in Toruń in the period of 1997-2016

Objaśnienia: 1 - \% dni z wezbraniami $(\geq 650 \mathrm{~cm}), 2$ - \% dni z niżówkami $(\leq 240 \mathrm{~cm})$.

Explanations: 1 - percentage of days with high $(\geq 650 \mathrm{~cm})$ water levels, 2 - percentage of days with low $(\leq 240 \mathrm{~cm})$ water levels.

analizowanym wieloleciu 1997-2016 okresy z niekorzystnymi warunkami żeglugowymi przypadają na czas trwania sezonu nawigacyjnego. Jak widać na ryc. 5, w ponad 50\% dni w miesiącach od lipca do października żegluga nie mogła się odbywać z uwagi na złe warunki nawigacyjne. Odpowiadały za to głównie dni z niżówkami. Należy wspomnieć, że w latach 2003, 2012 i 2015 we wspomnianych miesiącach stany wody utrzymywały się poniżej $240 \mathrm{~cm}$, co powodowało, że żegluga nie mogła się odbywać przez cały miesiąc (ryc. 5 i 6). Na ryc. 6 i 7 przedstawiono przebieg codziennych stanów wody Wisły w Toruniu wraz z liczbą średnich miesięcznych śluzowań w roku wilgotnym (2010 r.) i suchym (2015 r.).

Poza stanami wody, które mają duży wpływ na warunki nawigacyjne, kolejnym elementem utrudniającym żeglugę są zjawiska lodowe, które pojawiają się od listopada do kwietnia. $Z$ reguły w okresie tym nie prowadzono przewozów towarowych, a jednostki, które były śluzowane, to najczęściej lodołamacze. W ciągu ostatnich 100 lat nastąpiła zmiana czasu trwania zlodzenia na Wiśle. Czas trwania zjawisk 


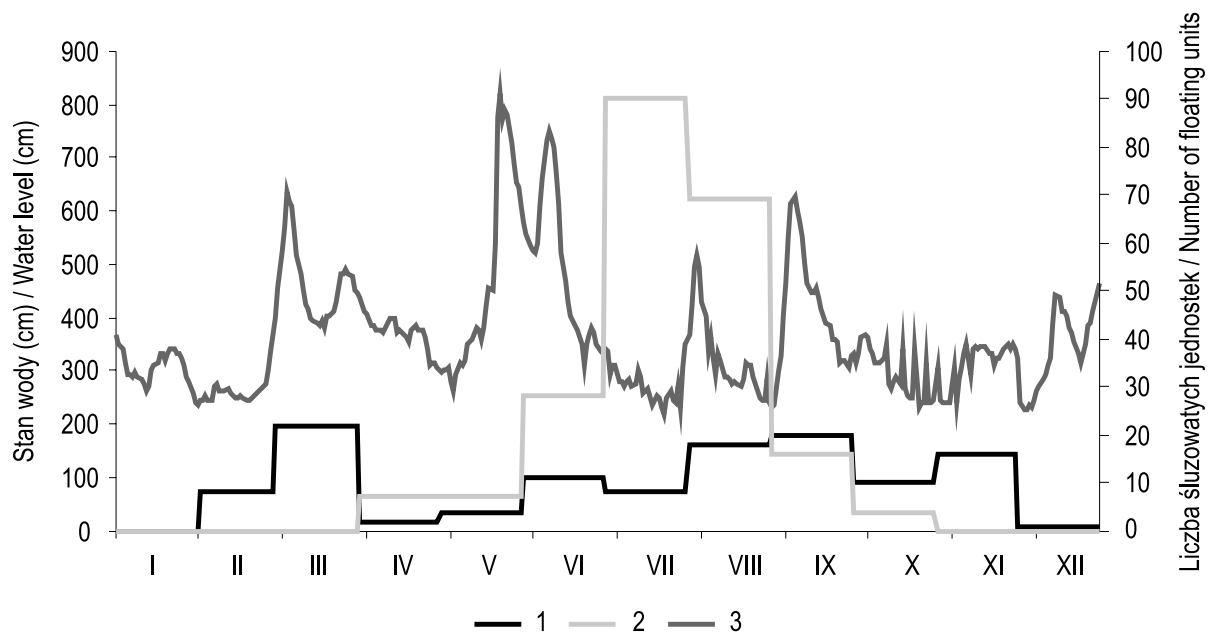

Ryc. 6. Przebieg stanów wody Wisły w Toruniu na tle średnich miesięcznych śluzowań we Włocławku w $2010 \mathrm{r}$.

Fig. 6. Course of water levels of the Vistula in Torun against the background of the average monthly number of lock passings in Włocławek in 2010

Objaśnienia: 1 - ruch towarowy, 2 - ruch turystyczny, 3 - stany wody w 2010 r. w cm.

Explanations: 1 - freight traffic, 2 - touristic traffic, 3 - water level in $2010 \mathrm{in} \mathrm{cm}$.

lodowych na Wiśle w Toruniu uległ skróceniu z ok. 100 dni do 50. Z kolei czas zalegania pokrywy lodowej skrócił się z 70 dni (pokrywa każdej zimy) do ok. 45 dni. Zanotowano, że pokrywa lodowa występowała raz na 5-8 lat (Grześ, Pawłowski 2008). Z uwagi na ten fakt sporadycznie można zaobserwować, że w ostatnich latach, kiedy zjawiska lodowe nie występują, systematycznie zwiększa się liczba jednostek śluzowanych w okresach listopad-marzec.

\section{Dyskusja}

Przeprowadzona analiza wykazała, że liczba jednostek śluzowanych przez stopień wodny we Włocławku jest zmienna w poszczególnych latach (średnio 375 jednostek), a w całym wieloleciu wykazuje tendencję spadkową. Dla porównania na bydgoskim odcinku drogi wodnej E-70 największe wykorzystanie mają śluzy położone na rzece Brdzie, tj. Czersko Polskie i Śluza Miejska. Na śluzach tych rocznie śluzuje się 3-krotnie więcej jednostek niż na śluzie we Włocławku. Na śluzie w Czersku Polskim dominował ruch towarowy (ponad $80 \%$ przewozów), związany głównie z wydobyciem 


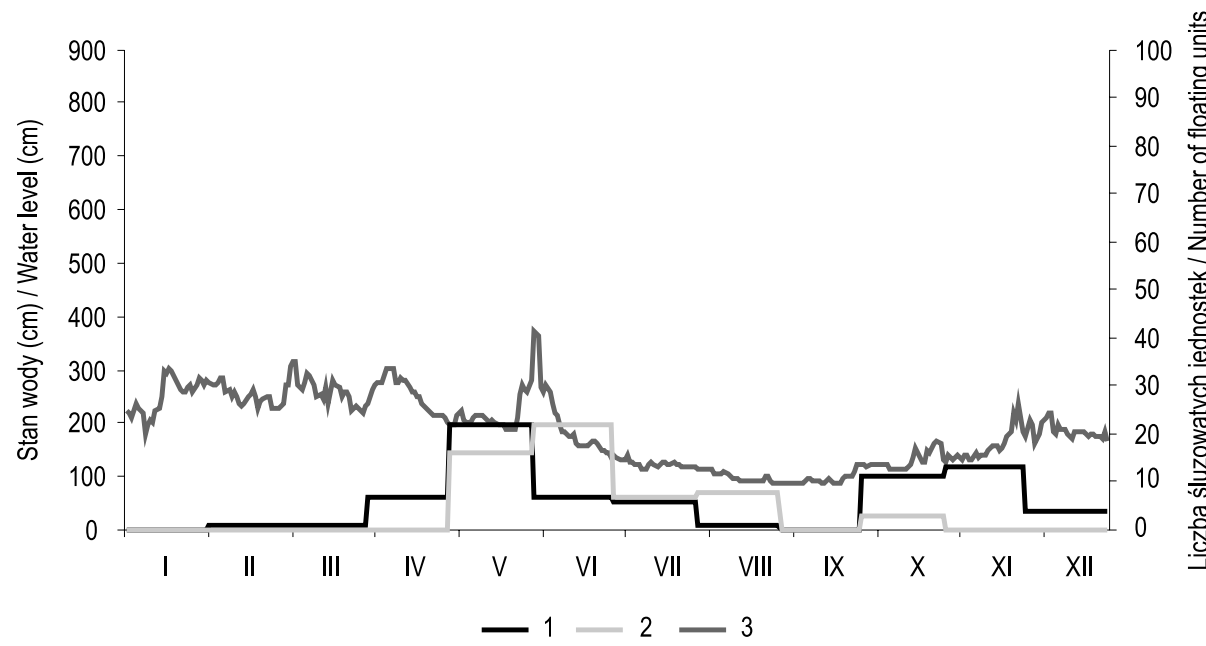

Ryc. 7. Przebieg stanów wody Wisły w Toruniu na tle średnich miesięcznych śluzowań we Włocławku w 2015 r.

Fig. 7. Course of water levels of the Vistula in Torun against the background of the average monthly lock passings in Włocławek in 2015

Objaśnienia: 1 - ruch towarowy, 2 - ruch turystyczny, 3 - stany wody w 2015 r. w cm.

Explanations: 1 - freight traffic, 2 - touristic traffic, 3 - water level in $2010 \mathrm{in} \mathrm{cm}$.

piasku i żwiru z dna Wisły dla potrzeb zakładu produkcyjnego w Solcu Kujawskim, natomiast na Śluzie Miejskiej dominował ruch turystyczny (Kubiak-Wójcicka 2014b). Liczba jednostek śluzowanych na Odrze w Brzegu Dolnym w 1999 r. była wyższa niż we Włocławku w tym samym roku o ok. 30\% (Woś 2010), jednak w późniejszych latach, np. w 2008 r., wielkość ta była porównywalna (Marszałek 2010). Uzyskane wartości dla obiektu we Włocławku świadczą o słabym wykorzystaniu drogi wodnej dolnej Wisły zarówno w przewozach lokalnych, jak i przewozach długodystansowych.

Wzrost zainteresowania przewozami towarowymi musi iść w parze z modernizacją drogi wodnej, która zapewni odpowiednie głębokości żeglugowe. Żegluga śródlądowa jest w dużej mierze uzależniona od warunków klimatycznych (Jurum-Kipke, Maković 2007; Bačkalić, Maslarić 2012). W przypadku wystąpienia długotrwałych niżówek nie ma możliwości zabezpieczenia terminowości przewozów ładunków, ponieważ przy zbyt małych głębokościach jednostki towarowe o dużej wyporności oraz duże statki pasażerskie pozostają w portach. Jak podają Hekkenberg i in. (2017), to właśnie czas i koszt transportu są decydującymi czynnikami dla spedytorów wybierających środek transportu. Poprawa żeglugi śródlądowej, 
poza modernizacją drogi wodnej dolnej Wisły, jest możliwa poprzez inwestycje w porty przeładunkowe. Porty te powinny mieć charakter intermodalny, co pozwoli na przewozy różnymi środkami transportu, zwłaszcza podczas niekorzystnych warunków hydrologicznych. Jedną z lokalizacji branych pod uwagę był Solec Kujawski, z uwagi na dogodne miejsce i budowę zaplecza portowego, bliskie położenie linii kolejowej i drogowej (Bolt, Jerzyło 2013a; Kubiak-Wójcicka 2016). Pierwsze kroki zostały już podjęte, m.in. przystąpiono do prac związanych z budową przeprawy przez Wisłę w Czarnowie do Solca Kujawskiego. Oficjalne uruchomienie promu ma nastąpić w 2019 r. W przypadku żeglugi śródlądowej istnienie takich portów wzdłuż drogi wodnej jest niezbędne do terminowego dostarczania ładunków. Port taki stanowiłby zaplecze dla portu morskiego w Gdańsku i Gdyni, co może rozwijać transport morsko-rzeczny. Pomyślna integracja portów morskich i terminali śródlądowych wymaga systematycznego podejścia (Rožić i in. 2016), które uwzględnia korzyści dla wszystkich zainteresowanych stron i poparta jest odpowiednią kalkulacją ekonomiczną.

Wzmożony ruch na drodze wodnej przyczyni się do powstania infrastruktury łączności, która obejmie system kontroli i nadzoru rzecznego, co podniesie bezpieczeństwo jednostek pływających (Królikowski, Rutkowski 2009). System Informacji Rzecznej (ang. River Information Service; RIS) jest obowiązkowy dla rzek znajdujących się w ramach międzynarodowej sieci śródlądowych dróg wodnych w państwach członkowskich Unii Europejskiej. System taki został wprowadzony na Odrze, która jest rzeką graniczną, natomiast na Wiśle nie został wprowadzony z uwagi na mały ruch. Poza zwiększeniem przewozów drogą wodną budowa portu intermodalnego przyczyni się do rozwoju całego regionu bydgosko-toruńskiego. Przypadek taki odnotowano w aglomeracji poznańskiej (Igliński 2014).

Sam transport wodny i jego możliwości rozwoju mają duży potencjał w przyszłości. $Z$ roku na rok wzrasta ilość przeładowanych towarów w porcie w Gdańsku, następuje dalsza rozbudowa portu. O wzroście znaczenia portu w Gdańsku w europejskiej sieci transportowej świadczy fakt, że Zarząd Portu Gdańsk został wymieniony na liście World Top Container Ports 2017 wśród 100 największych portów kontenerowych. W świetle tych doniesień należy rozpatrzyć możliwość rozwoju transportu kontenerowego, dzięki któremu dolna Wisła może pełnić ważną funkcję transportową na odcinku od Gdańska do Warszawy.

Wzrasta także zainteresowanie turystyką wodną, co wynika z organizacji wielu imprez plenerowych, ale również z mniej rygorystycznych przepisów w zakresie uprawiania turystyki wodnej. Budowa inwestycji w połączeniu z pracami modernizacyjnymi lub rewitalizacyjnymi przestrzeni nadrzecznych sprzyja większemu zainteresowaniu społeczeństwa. 


\section{Podsumowanie i wnioski}

Stopień we Włocławku odgrywa ważną, wręcz strategiczną rolę w ruchu żeglugowym na dolnej Wiśle, dlatego w niniejszym opracowaniu skupiono się wyłącznie na ruchu żeglugowym, jaki odbywa się na śluzie we Włocławku. W świetle przeanalizowanych danych należy uznać, że:

- liczba śluzowanych jednostek na śluzie we Włocławku uzależniona jest od sprawności technicznej śluzy oraz od warunków hydrologicznych, głównie niskich stanów wody w Wiśle;

- w ciągu roku transport wodny ma charakter sezonowy, największa liczba śluzowanych jednostek przypada głównie na miesiące letnie (VI-VIII);

- w strukturze transportu wodnego ruch towarowy dominuje nad ruchem turystycznym, wyjątek stanowią lata z niskimi stanami wody;

- zwiększenie ilości przewożonych towarów drogą wodną wymaga zapewnienia odpowiedniej głębokości tranzytowej na całym odcinku drogi wodnej. W obecnym stanie jest to niemożliwe z uwagi na zmienne stany wody w rzece (niżówki i wezbrania).

Należy się spodziewać, że w najbliższej perspektywie ruch turystyczny będzie przeważać nad ruchem towarowym, co wynika z aktualnego stanu technicznego dróg wodnych ściśle uzależnionych od warunków hydrologicznych. Zmiana tej sytuacji może nastąpić wówczas, gdy drogi wodne zostaną zmodernizowane w sposób zapewniający ich żeglowność. Zainteresowanie przewozami towarowymi drogami śródlądowymi będzie większe, gdy zwiększy się gwarancja dotrzymania terminów dostaw. Jest to możliwe przez budowę portów intermodalnych wzdłuż dróg wodnych, które będą stanowiły zaplecze przeładunkowe i w niekorzystnych sytuacjach nawigacyjnych umożliwią dalszy transport przy wykorzystaniu różnych środków transportu, np. kolejowego lub samochodowego. Tylko w takiej sytuacji żegluga śródlądowa będzie partnerem w transporcie zarówno krajowym, jak i międzynarodowym. W przypadku braku inwestycji ze strony państwa w poprawę stanu dróg wodnych śródlądowych zainteresowanie turystyką wodną nadal może wzrastać jedynie w połączeniu z imprezami organizowanymi przez poszczególne miasta i promocje terenów nadrzecznych.

\section{Literatura}

Babiński Z., 2013, Rewitalizacja dróg wodnych sæansq na przyworócenie ich «naczenia środowiskowego i gospodarczego (na przyktadzie dolnej Wisty - MDW E 40), Gospodarka Wodna, 6, 236-237.

Babiński Z., Habel M., 2013, Hydromorphological conditions of the lower Vistula in the development of navigation and hydropower, Acta Energetica, 2 (15), 83-90.

Bačkalić T., Maslarić M., 2012, Navigation conditions and the risk management in inland waterway transport on the middle Danube, Problemy Transportu, 7 (4), 13-24. 
Biała Ksiega Transportu, 2011, Plan utworzenia jednolitego europejskiego obsะaru transportu-dqżenie do osiagnięcia konkurencyjnego $i$ zasobooszczednego systemu transportu, TRANS 102, Rada Unii Europejskiej, Bruksela.

Bolt A., Jerzyło P., 2013a, Mo:́liwości rowwoju transportu kontenerowego na międzynarodowych drogach wodnych E-70 i E-40, Gospodarka Wodna, 6, 244-247.

Bolt A., Jerzyło P., 2013b, Determinants of inland navigation on the Vistula from Warsaw to Gdansk, Acta Energetica, 2 (15), 56-63.

Caris A., Limbourg S., Macharis C., van Lier T., Cools M., 2014, Integration of inland waterway transport in the intermodal supply chain: a taxonomy of research challenge, Journal of Transport Geography, 41, 126-136.

Duda-Gromada K., 2018, Tereny nad Wistq w Warszawie jako miejsce spotkań (w opinii mieszkańców wybranych osiedli), Prace Geograficzne, 152, 67-81. doi: 10.4467/20833113PG.17.031.8254.

Gorączko M., Szyplik J., Pasela R., 2013, Wpływ niżówek na warunki funkcjonowania ふ̇eglugi w rejonie Bydgoskiego Węzta Wodnego, Geography and Tourism, 1, 69-76.

Grześ M., Pawłowski B., 2008, Hydromorfologiczne wwarunkowania lodołamania na Wiśle od stopnia wodnego we Wtoctawku do ujscia z uwzględnieniem sezonu simowego 2011/2012, Regionalny Zarząd Gospodarki Wodnej, Gdańsk.

Hekkenberg R.G., van Dorsser C., Schweighofer J., 2017, Modelling sailing time and cost for inland waterway transport, European Journal of Transport and Infrastructure Research, 17 (4), 508-529.

Igliński H., 2014, Rozwój transportu intermodalnego a wærost aktywności inwestycyjnej aglomeracji poznańskiej, Logistyka, 2, 40-43.

Ivaković C., Rogić K., Orlić Protega A., 2008, Traffic on the Croatian inland waterways in the context on the European Programme Nainades, Promet - Traffic\&Transportation, 20 (6), 383-393.

Jarzębińska T., 2008, Rola polskich dróg wodnych sródlądowych w sieci europejskiej [w:] Z. Babiński (red.), Rewitalizacja drogi wodnej Wista-Odra szansq dla gospodarki regionu, Bydgoszcz, 13-19.

Jurum-Kipke J., Maković B., 2007, Current condition of vessels on inland waterways in Croatia, Promet - Traffic\&'Transportation, 19 (5), 301-309.

Królikowski A., Rutkowski G., 2009, Analiza istniejąych na świecie systemów nawigacyjnych jednostek w żegludze śródlqdowej, Zeszyty Naukowe Akademii Morskiej w Gdyni, 63, 35-46.

Kruczek Z., Banasik W. (red.), 2014, Dynamika przemian rynku turystycznego, Wyższa Szkoła Turystyki i Języka Obcego, Stowarzyszenie Ekspertów Turystyki, Warszawa.

Kubiak-Wójcicka K., 2012, Charakterystyka niżówek na Wiśle w Toruniu [w:] W. Marszelewski (red.), Gospodarowanie wodq w warunkach smieniajqcego się środowiska, Monografie Komisji Hydrologicznej PTG, Toruń, 85-94.

Kubiak-Wójcicka K., 2014a, Wezbrania na Wišle w Toruniu w świetle obserwacji historycznych [w:] T. Ciupa, R. Suligowski (red.), Woda w mieście, Monografie Komisji Hydrologicznej, Kielce, 127-134.

Kubiak-Wójcicka K., 2014b, Stopień wykorzystania infrastruktury liniowej w ふ̇egludze śródlqdowej na przyktadzie bydgoskiego odcinka międzynarodowej drogi wodnej E-70, Logistyka, 6, 12820-12832. 
Kubiak-Wójcicka K., 2016, Hydrologiczne uwarunkowania budowy i funkcjonowania intermodalnego portu ræecznego w Solcu Kujawskim, Logistyka, 3, 129-136.

Kubiak-Wójcicka K., Chodkowska-Miszczuk J., Rogatka K., 2017, Integration or disintegration of the ecological and urban functions of the river in the city? A Polish perspective, Transylvanian Review of Administrative Sciences, 52, 59-76. doi:10.24193/tras.52E.4.

Kulczyk J., Winter J., 2003, Śródlądowy transport wodny, Oficyna Wydawnicza Politechniki Wrocławskiej, Wrocław.

Lopez Navarro M.A., 2013, The Effect of shared planning by road transport firms and shipping companies on performance in the intermodal transport chain: the case of Ro-Ro Short Sea Shipping, European Journal of Transport and Infrastructure Research, 13 (1), 39-55.

Marszałek E., 2010, Odra jako szlak komunikacyjno-transportowy oraz turystyczny [w:] Krajobrazy kulturowe dolin ræecznych. Potencjat $i$ wykorzystanie, Prace Komisji Krajobrazu Kulturowego, 13, 204-216.

Mika M., 2000, Turystyka jako czynnik præemian środowiska przyrodniczego - stan badań, Prace Geograficzne, 106, 73-98.

Montwiłł A., 2013, Węłty transportowe we europejskim systemie transportu i tańcuchach dostaw, Logistyka, 6, 948-957.

Najwyższa Izba Kontroli, 2013, Informacja o wynikach kontroli: Funkcjonowanie ṡeglugi śródlqdowej, KIN-4101-04/2013, nr ewid. 188/2013/P/13/079/KIN.

Organizacja Współpracy Gospodarczej i Rozwoju, 1996, Toward Sustainable Transportation, The Vancouver Conference 24-27 March, Vancouver, British Columbia.

Rohács J., Simongáti G., 2007, The role of inland waterway navigation in a sustainable transport system, Transport, XXII (3), 148-153.

Rosporzqdzenie Rady Ministrów \& dnia 7 maja 2002 roku w sprawie klasyfikacji śródladowych dróg wodnych (Dz. U. 2002. Nr 77, poz. 695).

Rosporzqdzenie Ministra Sportu i Turystki \& dnia 9 kwietnia 2013 roku w sprawie uprawiania turystyki wodnej (Dz. U. 2013, poz. 460).

Rožić T., Rogić K., Bajor I., 2016, Research trend of inland terminals: a literature review, Promet - Traffic\&Transportation, 28 (5) 539-548.

Smolnik P., 2016, Assumption of state policy concerning inland waterways in Poland, Scientific Journals of the Martime University of Szczecin, 47 (119), 154-159. doi: 10.17402/163.

Strategia rozwoju transportu do 2020 roku (z perspektywa do 2030 roku), 2013, Ministerstwo Transportu, Budownictwa i Gospodarki Morskiej, Warszawa.

Taylor Z., Ciechański A., 2011, Oganizational restructuring and ownership transformation in Poland's inland shipping companies after 1990, Geographica Polonica, 84 (2), 77-92.

Transport wody śródlądowy w Polsce w 2016 r., 2017, Główny Urząd Statystyczny, Warszawa, http://stat.gov.pl/obszary-tematyczne/transport-ilacznosc/transport/transport-wodny-srodladowy-w-polsce-w-2016-roku,4,7.html.

Wiegmans B., Konings R. (red.), 2017, Inland waterway transport. Challenges and prospects, Routledge, New York. 
Wojewódzka-Król K., 1987, Wspótzaleṡności ekonomiczne w rozwoju infrastruktury śródladowych dróg wodnych, Zeszyty Naukowe Uniwersytetu Gdańskiego, Rozprawy i monografie, 102, Gdańsk.

Wojewódzka-Król K., Rolbiecki R., 2013, Grounds and opportunities for the development of the passenger and cargo shipping on the lower Vistula, Acta Energetica, 2 (15), 106-112.

Woś K., 2010, Żegluga śródlądowa - szanse rozwoju. Szczecin, (http://www.am.szczecin.pl/ userfiles/File/aktualnosci/news_2010_03_02/KW-zegluga_srodladowa-szanse_rozwoju. pdf) (dostęp: 1.10.2014).

Katarzyna Kubiak-Wójcicka

Uniwersytet Mikotaja Kopernika

Wydziat Nauk o Ziemi

Katedra Hydrologii i Gospodarki Wodnej

ul. Lwowska 1, 87-100 Toruń

kubiak@umk.pl

Tomasz Pokropski

Państwowe Gospodarstwo Wodne WODY POLSKIE

Regionalny Zarzad Gospodarki Wodnej w Warsæawie

Zaræad Zlewni we Wtoctawku

ul. Okrzei 74A, 87-800 Wtoctawek

tomasw.pokropski@wody.gov.pl 